\section{ШЛЯХИ УДОСКОНАЛЕННЯ СИСТЕМИ ДЕРЖАВНИХ ЗАКУПІВЕЛЬ В УМОВАХ ДЕЦЕНТРАЛІЗАЦІї}

\section{WAYS TO IMPROVE THE PUBLIC PROCUREMENT SYSTEM IN THE CONDITIONS OF DECENTRALIZATION}

\author{
ЧЕЧЕЛЬ А. О., \\ доктор економічних наук, доцент, \\ завідувач кафедри публічного \\ управління та адміністрування, \\ ЧЕРНИШОВ О. Ю., \\ кандидат економічних наук, \\ доцент, доцент кафедри \\ менеджменту виробничої та \\ невиробничої сфери, \\ IГНАТОВ А. O., \\ магістрант кафедри публічного \\ управління та адміністрування, \\ Донецький державний \\ університет управління
}

\author{
CHECHEL A., \\ Doctor of Science in Economics, \\ Associate Professor, Head of the \\ Department of Public \\ Administration, \\ CHERNYSHOV O., \\ $\mathrm{PhD}$ in Economics, Associate \\ Professor, Associate Professor of \\ the Department of Non-Production \\ Management, \\ IGNATOV A., \\ Master's Degree student of the \\ Department of Public \\ Administration, Donetsk State \\ University of Management
}

Розроблено та обтрунтовано пропозиції щзодо вдосконалення системи управління державними закупівлями в Украӥні, серед яких інституційноорганізаційні та оперативні заходи вирімення проблем, формування державної контрактної системи. Особлива роль відводиться інновачійній компоненті планування закупівель замовниками та постачальниками. У статті проаналізовано перспективи трансформачії системи державних закупівель Украӥни в електронний формат. Обгрунтовано, що створення системи електронних торгів дозволить суттєво зменшити витрати державних коштів замовниками торгів на придбання предметів закупівлі, організацію та проведення закупівельного прочесу.

Ключові слова: державні закупівлі, організаційно-управлінські механізми, контрактна система, закупівельна стратегія, інноваційна компонента.

Разработаны $и$ обосновань предложения относительно усовершенствования системы управления государственными закупками в Украине, среди которых институциональноорганизационные $и$ оперативные мероприятия решения проблем, формирование государственной контрактной системы. Особенная роль отводится инновачионному компоненту планирования закупок заказчиками и поставщиками. B статье проанализированы перспективы трансформации системы государственных закупок Украины в электронный формат. Обосновано, что создание системы электронных 
торгов позволит существенно уменьшить расходы государственных средств заказчиками торгов на приобретение предметов закупки, организацию и проведение закупочного прочесса.

Ключевые слова: государственные закупки, организачионноуправленческие механизмы, контрактная система, закупочная стратегия, инновационный компонент.

It is developed and grounded suggestion in relation to the improvement of control system public purchasing in Ukraine, among which institutional and organizational and operative measures of decision of problems, forming of the state contract system. Osoblva a role is taken to innovative component of planning of purchases customers and suppliers. The article analyzes the prospects for the transformation of Ukraine's public procurement system into an electronic format. It is substantiated that the creation of an electronic bidding system will significantly reduce the cost of public funds by bidders for the purchase of procurement items, organization and conduct of the procurement process.

Keywords: public purchasing, organizational-administrative mechanisms, contract system, purchase strategy, innovative component.

Постановка проблеми. Серед найважливіших проблем сучасного економічного розвитку України особливе місце займає проблема підвищення ефективності використання та витрачання державних ресурсів для забезпечення економічної безпеки та стійкого розвитку національної економіки. Одним 3 методів державного регулювання економіки $\epsilon$ функціонування системи державних закупівель. Державним закупівлям відводиться роль перспективного та важливого макроекономічного регулятора, за допомогою якого можливе формування повноцінного конкурентного середовища, здійснення стабілізаційної політики в країні.

Державні закупівлі постійно привертають публічну увагу як потенційне джерело корупції, невиправданих розтрат коштів платників податків. Усупереч поширеній думці, корупція при здійсненні державних закупівель не $є$ феноменом, властивим виключно Україні та іншим країнам, що розвиваються.

Аналіз останніх досліджень і публікаиій. Аналіз останніх досліджень та публікацій. Питання «закупівель» за державні кошти досліджувало багато вчених, зокрема, О. Алтинцева, В. Морозова, В. Смиричинський, Н. Ткаченко, Н. Хорунжак, Н. Несторович, В. Вареник [2, с. 6], Е.Ф. Демський, О.П. Кулак, А.Є. Никифоров, О.Ф. Овсянюк-Бердадіна, А.О. Олефір, А.Б. Павловський, С.М.Чистов та інші. Однак ця тема $є$ відносно молода для нашої країни і потребує більш детального вивчення, а в подальшому розумного використання інформації як набутого досвіду. Однак, попри широку репрезентативність і представленість обраного 
проблемного напрямку досліджень, невирішеними продовжують залишатись низка питань, одним 3 яких $\epsilon$ забезпечення ефективності використання державних коштів.

Mema cmammi - дослідження теоретичних засад державного сектору, процесу формування та нормативно-правового забезпечення управління закупівлями в державному секторі.

Виклад основного матеріалу дослідження. Відповідно доп.6 ч.1 ст.1 Закону України «Про публічні закупівлі» електронна система закупівель це інформаційно-телекомунікаційна система, яка забезпечує проведення процедур закупівель, а також створення, розміщення, оприлюднення інформації, обмін інформацією й документами в електронному вигляді, до складу якої входить веб-портал уповноваженого органу (тобто система Prozorro), авторизовані електронні майданчики, між якими забезпечено автоматичний обмін інформацією та документами. Система створена таким чином, що будь-який вплив на учасників процедури закупівлі не чинить ані держава, ані адміністратори системи.

Міністерством економічного розвитку і торгівлі України ведеться постійний моніторинг використання електронної системи закупівель користувачами, аналізується практика застосування Закону, а також пропозиції щодо покращення роботи електронної системи закупівель та вдосконалення нормативної бази сфери публічних закупівель.

Електронна система закупівель необхідна для того, щоб забезпечити прозорість процесу державних закупівель, підвищити довіру бізнесу до держави й ефективність у боротьбі з корупцією. На фінансових ринках України акумулюється достатня кількість бюджетних коштів, яка потрібна для того, щоб створити конкуренцію в цьому сегменті [1]. До електронної системи державних торгів мають доступ представники як малого, так i середнього бізнесу. Нині це доволі спрощена процедура. Використання зазначеної системи дає змогу економити бюджетні кошти, дозволяє населенню контролювати процес торгів, що сприяє виконанню принципу відкритості у витрачанні бюджетних коштів. Оскільки система є відкритою, кожна особа (журналіст, громадський активіст або пересічний громадянин) може прослідковувати процес торгів, побачити, хто виграв тендер, які були умови та пропозиції щодо конкретного контракту. Початок роботи системи Рrozorro став результатом праці групи громадських активістів, IT- компаній i комерційних електронних торговельних майданчиків за підтримки державних органів [3, с. 82].

Електронні закупівлі передбачають чотири етапи. Кожному 
наступному етапу передуватиме широке ознайомлення більшості замовників зі здобутками попереднього етапу 3 метою поступового нарощування потенціалу державного та приватного секторів. Методика роботи в системі електронних закупівель «Рrozorro» передбачає кілька етапів, що відображені на рис. 1.

Замовник на першому етапі, на підставі плану закупівель та додатку до нього, затвердженого тендерним комітетом установи-замовника, подає на електронний майданчик в Інтернеті оголошення про те, що хоче закупити або які послуги потрібно отримати. Після розміщення оголошення кілька днів триває період уточнень.

На другому етапі проводяться електронні аукціони, де учасники знижують ціни. Замовник не має змоги впливати на ці процеси.

На третьому етапі замовник визначає переможця торгів. Основним критерієм при визначенні переможця $є$ ціна. Учасники торгів можуть оскаржувати торги в АМКУ.

Четвертим, етапом торгів $є$ укладання договору 3 переможцем, поставка товарів, виконання робіт і послуг та оплата.

Етап 1. Подання на електронний майданчик в Інтернеті оголошення про те, що замовник хоче закупити або які послуги потрібно отримати

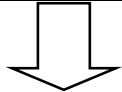

Етап 2. Проведення електронних аукціонів

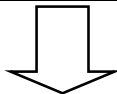

Етап 3. Замовник визначає переможця торгів

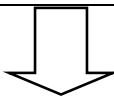

Етап 4. Укладання договору з переможцем, поставка товарів, виконання робіт і послуг та оплата

Рис. 1. Загальна методика роботи в системі електронних закупівель «Prozorro»

Цінові пороги, або «граничні значення», «порогові показники», «порогові суми», «вартісні пороги», «фінансові межі», є одним із ключових елементів кожної системи публічних закупівель, адже вони визначають необхідність застосування законодавства, що регулює відносини у сфері державних закупівель. 
Під «порогами» в законодавствах різних країн світу про публічні закупівлі розуміються числові показники національної або євровалюти, 3 яких починається використання загального механізму проведення публічних закупівель, адже при досягнені законодавством СС процедури розміщення замовлень та проведення закупівель [4, с. 36].

Під час визначення цінових порогів для закупівель слід керуватися Законом України «Про публічні закупівлі» № 922-УШ від 25.12. 2018 р. (далі-Закон №922) [8] передбачені типи закупівель в електронній системі.

На рис. 2 надано більш широкий порівняльний аналіз допорогових закупівель, надпорогорих та європейських торгів.

\begin{tabular}{|c|c|c|}
\hline \multicolumn{3}{|c|}{ ДОПОРОГОВІ ЗАКУПІВЛІ } \\
\hline ЗВИЧАЙНІ ЗАМОВНИКИ & $\begin{array}{c}\text { ЗАМОВНИКИ } \\
\text { МОНОПОЛІСТИ }\end{array}$ & $\begin{array}{c}\text { ЯК ПРОВОДИТИ } \\
\text { ЗАКУПІВЛЮ }\end{array}$ \\
\hline \multicolumn{2}{|c|}{ до 50 тис. грн. } & $\begin{array}{c}\text { пряма закупівлля або через } \\
\text { ProZorro (від } 3 \text { тис. грн) }\end{array}$ \\
\hline $\begin{array}{c}\text { від } 50 \text { до 200 тис. грн для } \\
\text { товарів та 1,5 млн грн для } \\
\text { робіт }\end{array}$ & $\begin{array}{c}\text { від } 50 \text { до } 1 \text { млн грн для } \\
\text { товарів та } 5 \text { млн грн для } \\
\text { робіт }\end{array}$ & $\begin{array}{c}\text { пряма закупівлля або через } \\
\text { Prozorro або звіт (вимог до } \\
\text { термінів та документів } \\
\text { немає) }\end{array}$ \\
\hline
\end{tabular}

\begin{tabular}{|c|c|c|}
\hline \multicolumn{3}{|c|}{ УКРАЇНСЬКІ ПОРОГИ } \\
\hline ЗВИЧАЙНІ ЗАМОВНИКИ & $\begin{array}{c}\text { ЗАМОВНИКИ } \\
\text { МОНОПОЛІСТИ }\end{array}$ & $\begin{array}{c}\text { ЯК ПРОВОДИТИ } \\
\text { ЗАКУПІВЛЮ }\end{array}$ \\
\hline від 200 тис. грн до 133 тис. & від 1 млн грн до 133 тис. & Відкриті торги (15 днів) \\
євро для товарів та від 1,5 & євро для товарів та від 5 & Конкурентний діалог \\
млн грн до 5,15 млн грн до & млн грн до 5,15 млн грн до & Переговорна процедура \\
5,15 млн євро для робіт & 5,15 млн євро для робіт & \\
\hline
\end{tabular}

\begin{tabular}{|c|c|c|}
\hline \multicolumn{3}{|c|}{ ЄВРОПЕЙСЬКІ ПОРОГИ } \\
\hline ЗВИЧАЙНІ ЗАМОВНИКИ & $\begin{array}{c}\text { ЗАМОВНИКИ } \\
\text { МОНОПОЛІСТИ }\end{array}$ & $\begin{array}{c}\text { ЯК ПРОВОДИТИ } \\
\text { ЗАКУПІВЛЮ }\end{array}$ \\
\hline $\begin{array}{c}133 \text { тис. євро для товарів та } \\
\text { 5,15 млн євро для робіт }\end{array}$ & $\begin{array}{c}\text { від } 1 \text { млн грн до } 133 \text { тис. } \\
\text { євро для товарів та від } 5 \\
\text { млн грн до 5,15 млн грн до } \\
\text { 5,15 млн євро для робіт }\end{array}$ & $\begin{array}{c}\text { Відкриті торги (30 днів) } \\
\text { Конкурентний діалог } \\
\text { Переговорна процедура }\end{array}$ \\
\hline
\end{tabular}

Рис. 2. Порівняльна таблиця визначення порогів

Як бачимо зі схеми, незважаючи на те, що Закон № 922 регулює здійснення саме процедурних закупівель, він частково поширюється і на 
допорогові закупівлі: якщо їх очікувана вартість $\geq 50$ тис. грн $\mathrm{i} \leq$ вищенаведеним на схемі вартісним порогам [5].

Умови закупівлі (пороги, процедури) можуть варіювати в залежності від типу замовника. Визначення замовників за типами окреслене в Законі України «Про публічні закупівлі» (стаття 1).

Важливість державних закупівель зумовлено спрямованістю їх на розв'язання економічних, соціальних та інших проблем, що стоять перед державою.

Аналіз використання та впровадження системи Prozorro показав, що на поточний момент вона дуже активно використовується учасниками електронних торгів.

Система електронних закупівель Prozorro в Україні діє більше двох років і набула вагомого значення в організації державних закупівель.

Вже можна зробити певні висновки про функціонування та динаміку проведення закупівель у державному секторі за останній рік, коли використання електронної системи закупівель набуло обов'язкового характеру (табл. 1).

Таблиця 1

Динаміка застосування електронних закупівель вдержаному секторі

\begin{tabular}{|c|c|c|c|c|}
\hline $\begin{array}{c}\text { Показник в } \\
\text { системі } \\
\text { РгоZоrro }\end{array}$ & 2018 p. & 2019 р. & $\begin{array}{c}\text { Абсолютне } \\
\text { відхилення в } \\
\text { млн } \\
2019-2018 \mathrm{pp.}\end{array}$ & $\begin{array}{c}\text { Відсоток } \\
\text { зростання } \\
2019-2018 \\
\text { рр. }\end{array}$ \\
\hline $\begin{array}{c}\text { Кількість } \\
\text { процедур }\end{array}$ & 1,00 млн. & 2,62 млн. & 1,62 млн. & $162 \%$ \\
\hline $\begin{array}{c}\text { Кількість } \\
\text { замовників }\end{array}$ & 0,027 млн. & 0,0345 млн. & 0,0075 млн. & $27,78 \%$ \\
\hline $\begin{array}{c}\text { Кількість } \\
\text { учасників }\end{array}$ & 0,035 млн. & $\begin{array}{c}0,20366 \\
\text { млн. }\end{array}$ & 0,16866 млн. & $481,89 \%$ \\
\hline $\begin{array}{c}\text { Сума } \\
\text { оголошених } \\
\text { торгів }\end{array}$ & 777700 & $\begin{array}{c}198000000 \\
\text { млн. }\end{array}$ & 1202300 млн. & $154,6 \%$ \\
\hline $\begin{array}{c}\text { Сума } \\
\text { зекономлених } \\
\text { коштів }\end{array}$ & 27100 млн. & 67760 млн. & 40600 млн. & $150,04 \%$ \\
\hline
\end{tabular}

В даній таблиці розглянуто динаміку застосування, та абсолютне відношення визначено в мільйонах, та окреслено відсоток зростання за 2018-2019 роки. 
Варто звернути увагу на аналітичні таблиці, які дають зрозуміти швидкість, ефективність застосування електронних закупівель (рис. 3 - 5).

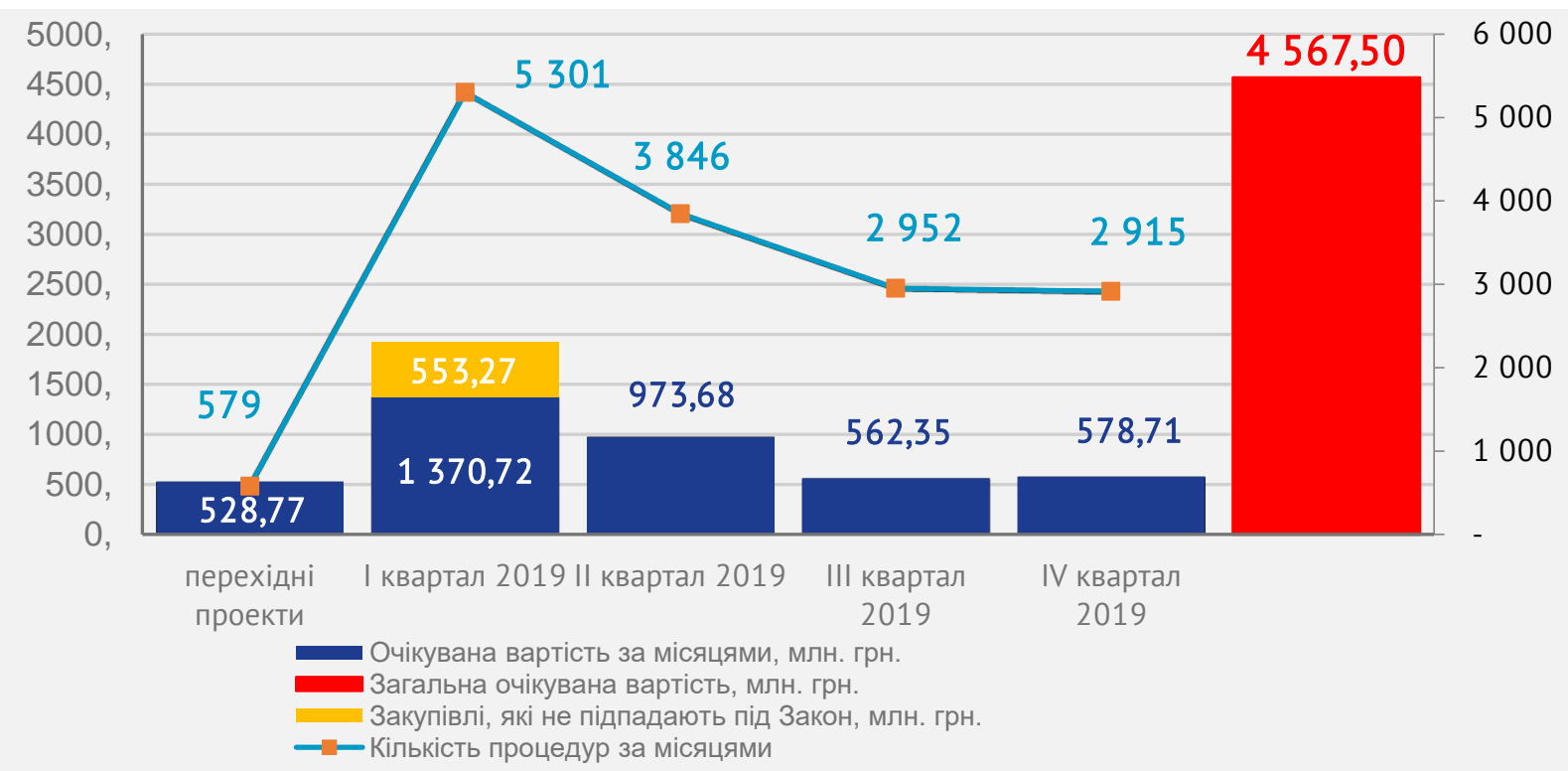

Рис. 3. Розподілення очікуваної вартості по завершеним процедурам за 2019 рік

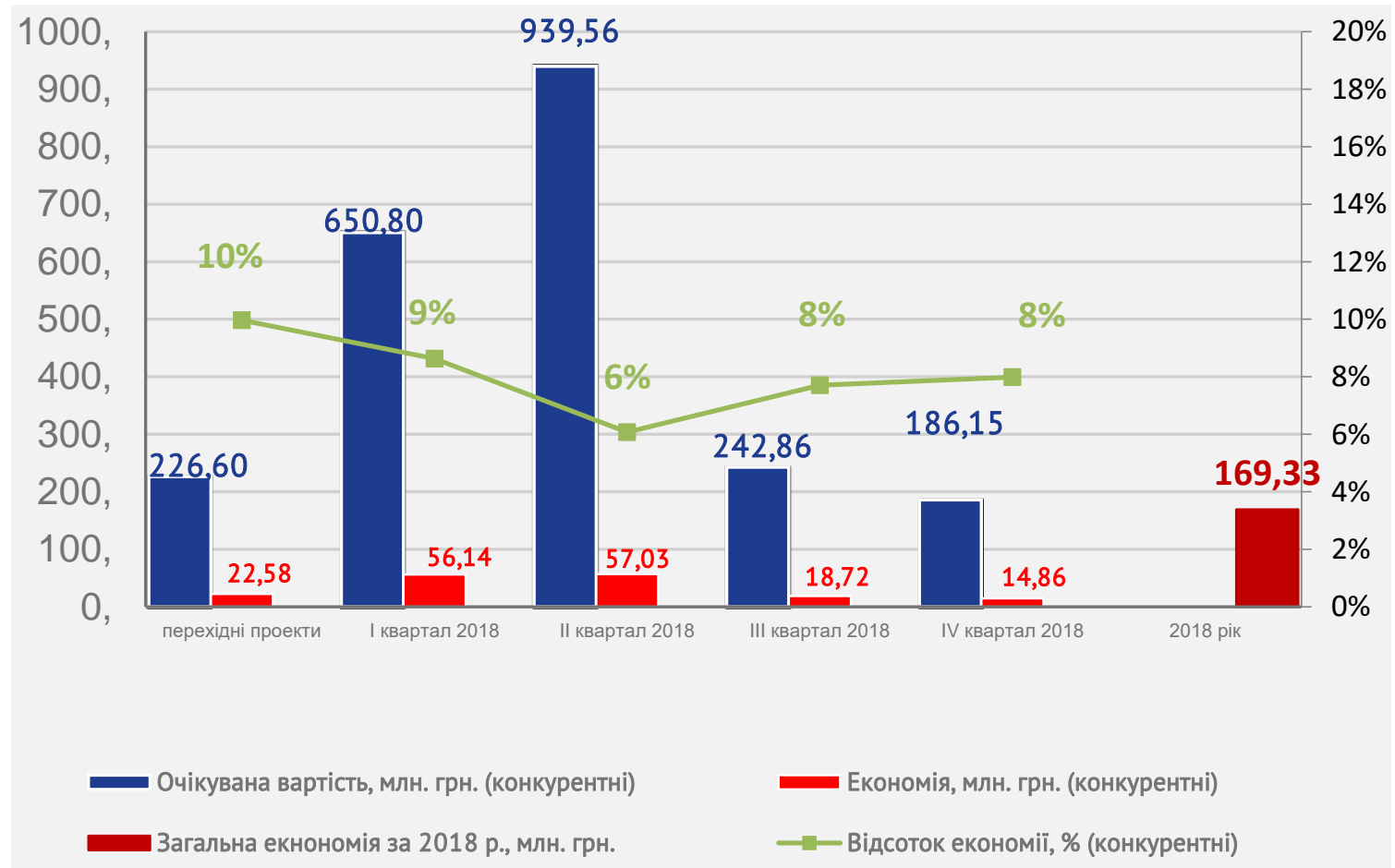

Рис. 4. Бенчмаркінг розподілення економії за конкурентними процедурами за 2019 рік 


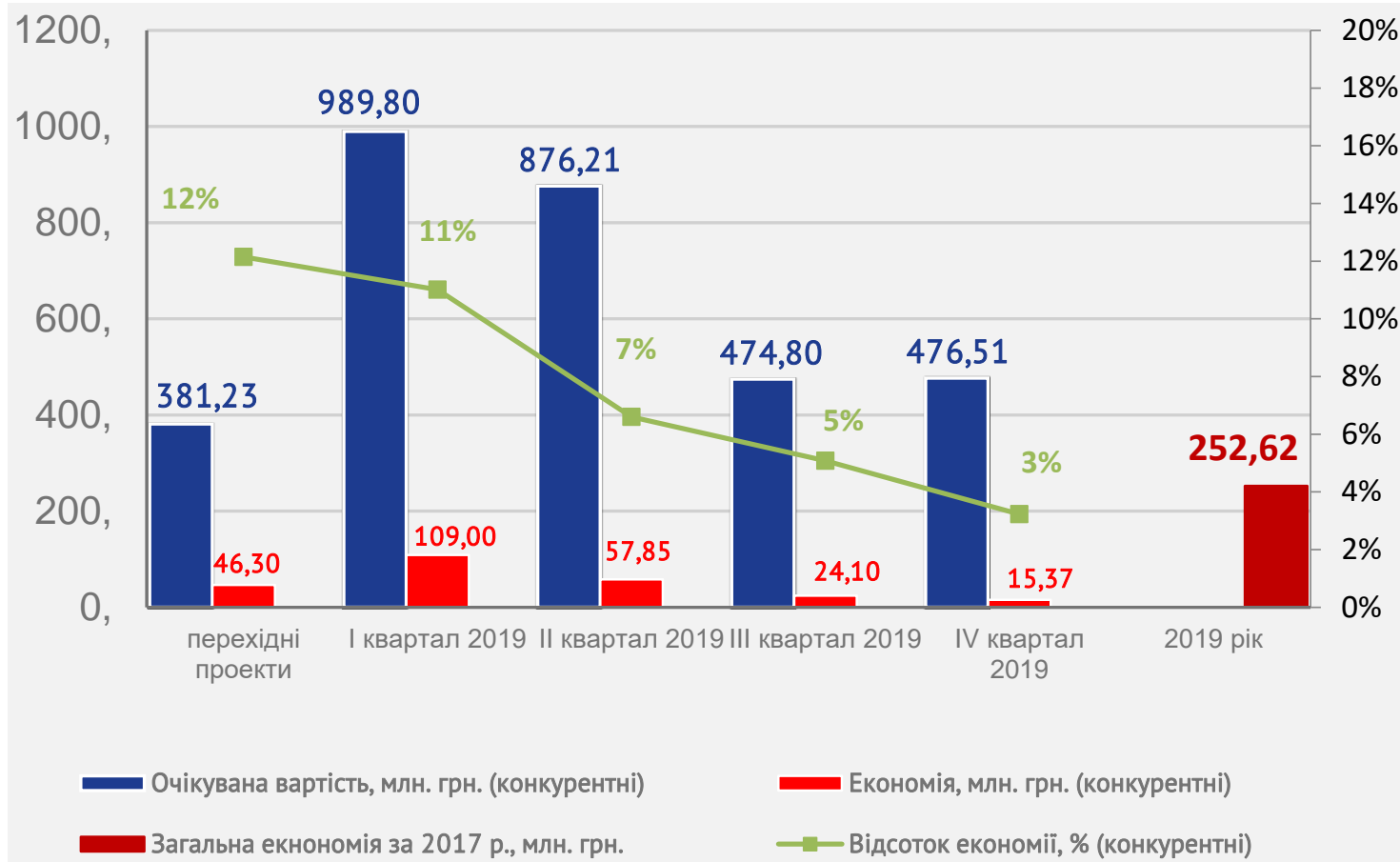

Рис. 5. Бенчмаркінг розподілення економії за конкурентними процедурами за 2019 рік

Показники конкуренції за завершеними процедурами, проведеними установами, підзвітними Маріупольській міській раді представлені на рис. $6-9$.

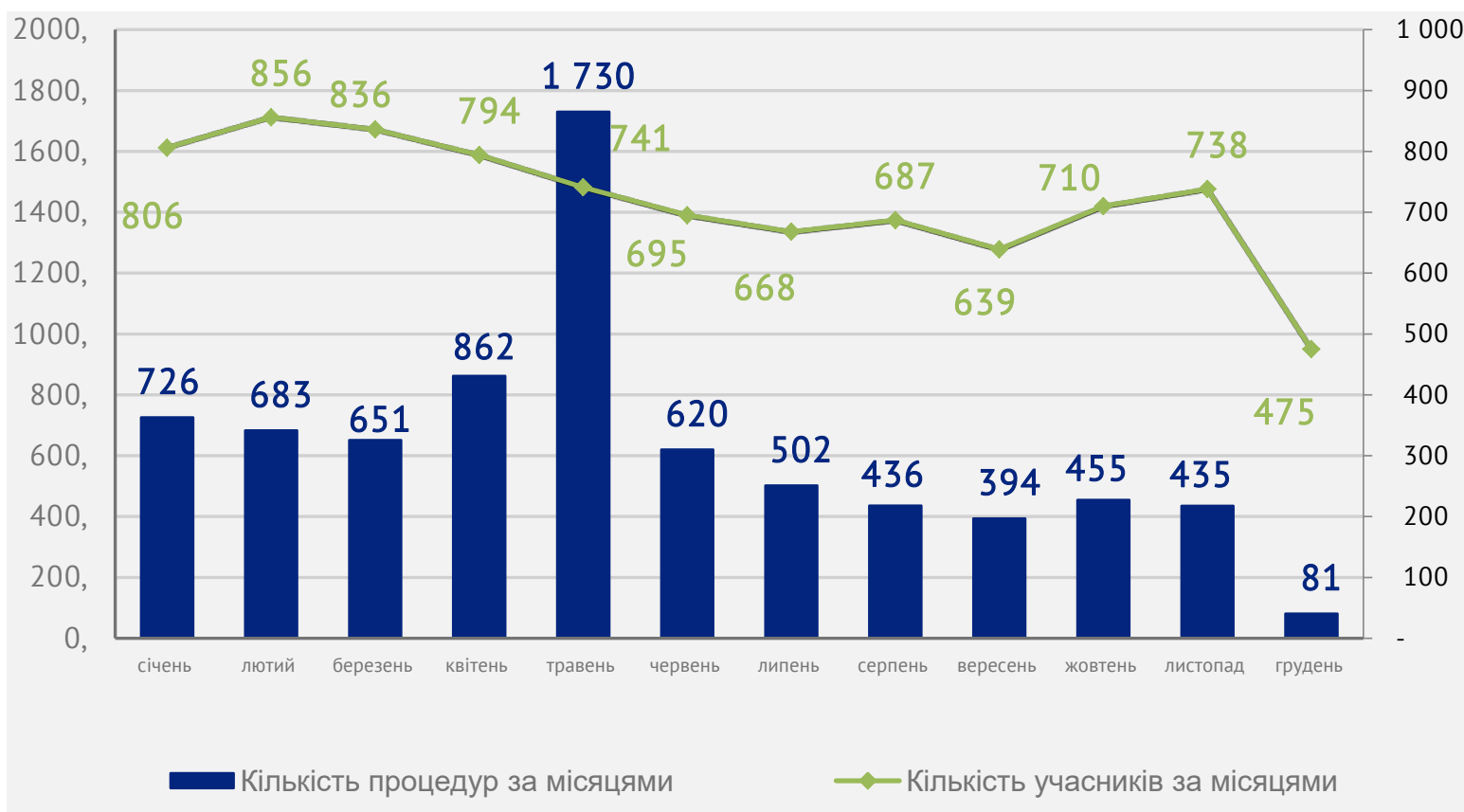

Рис. 6. Бенчмаркінг розподілення кількості учасників за конкурентними процедурами за 2019 рік 


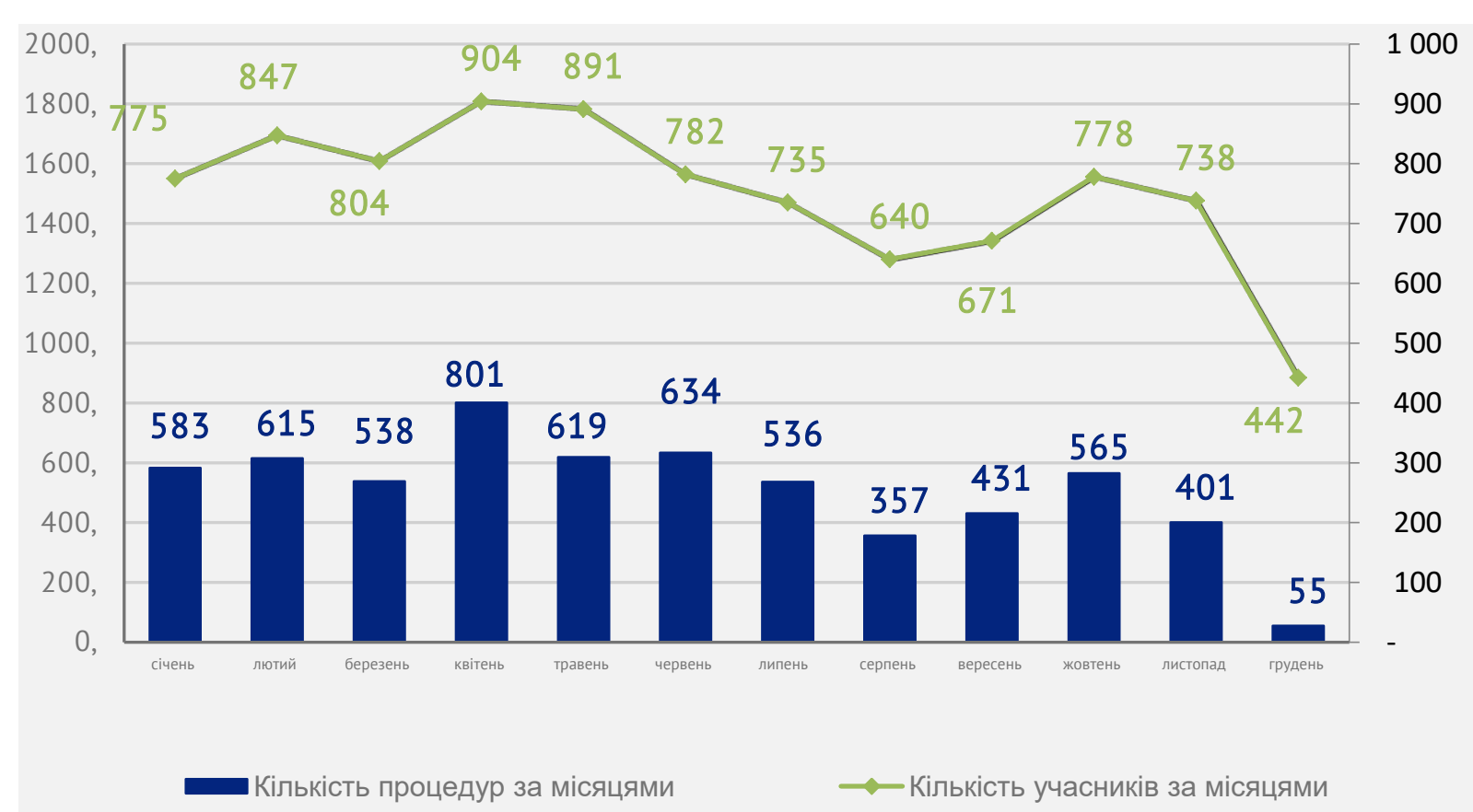

Рис. 7. Бенчмаркінг розподілення кількості учасників за конкурентними процедурами за 2019 рік

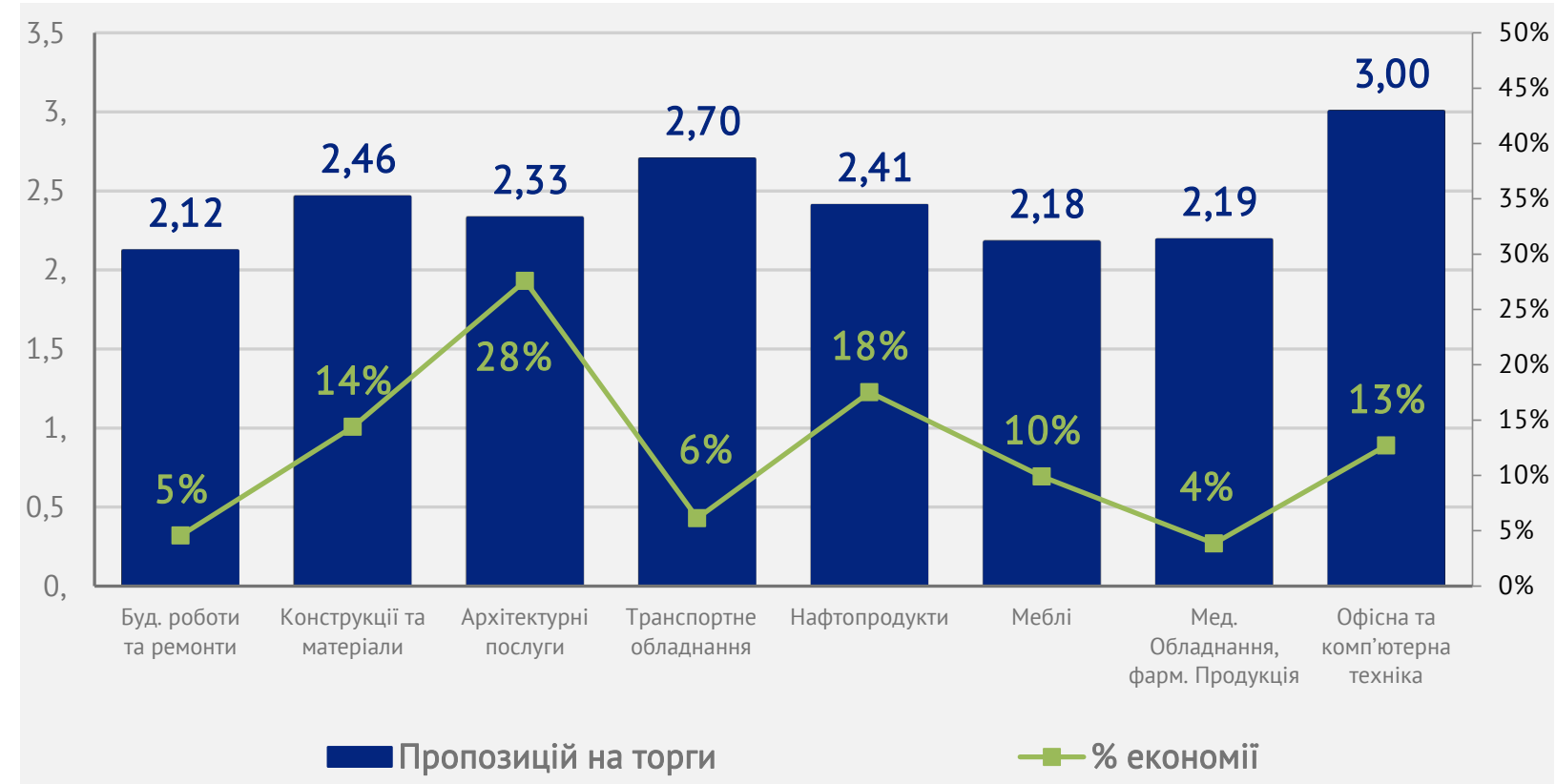

Рис. 8. Розподілення економії по основним напрямам закупівель за 2019

Iз зазначеного можна зробити висновок, що застосування електронних закупівель ProZorro спочатку в рамках пілотного проєкту в межах допорогових закупівель у 2019 році, а згодом із прийняттям відповідних законодавчих актів щодо обов'язкового використання єдиної електронної системи для державних закупівель, має свої позитивні наслідки. Головними перевагами даного закону є ефективне планування та 
використання державних грошей і часу, прозорість і відкритість, зручність використання, як для постачальників, так i для закупівельників, мобільність, можливість доступу до системи з будь-якої точки країни, (тільки присутня зайва паперова тяганина) [6].

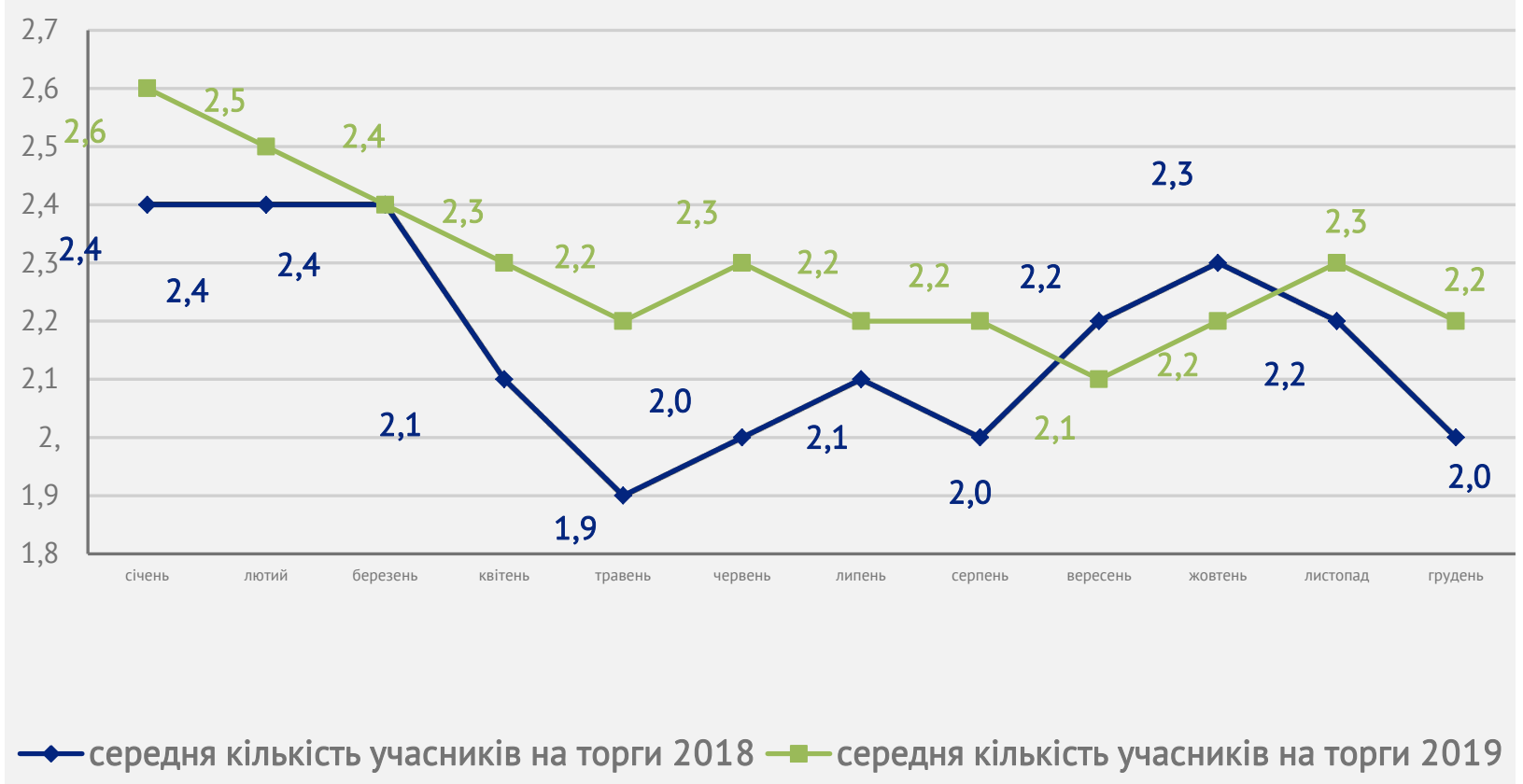

Рис. 9. Бенчмаркінг розподілення середньої кількості учасників на торги за конкурентними процедурами за 2019 (середня кількість - 2,1) - 2019 р (середня кількість - 2,3)

Економія коштів здійснюється завдяки зниженню бар'єрів доступу, особливо для малого та середнього бізнесу, в результаті збільшення конкуренції отримуємо нижчу ціну для державних замовників. Загальна економія за завершеними закупівлями, що здійснювались через систему електронних закупівель «Prozorro» становить близько 16 млрд грн (станом на травень 2019 року).

Сума економії в даному випадку - це різниця між очікуваною вартістю закупівлі та сумою коштів, що фактично перерахована з бюджету на рахунок постачальника товару чи послуг. Таким чином, Україна змогла зекономити на запуску технологій і тепер забезпечує висококонкурентний сервіс для державних компаній i бізнесу. Варто зазначити, що такі електронні аукціони (як окремі процедури) доцільно використовувати як короткострокове рішення для зниження цін і підвищення прозорості закупівель, у довгостроковій перспективі вони не зможуть вирішити основні проблеми, які існують у сфері державних закупівель в Україні. 
Після цього важливо побудувати систему ризик-мендженту, запроваджувати відкриті каталоги, працювати з базою специфікації, тобто реформа є комплексним продуктом [7, с. 32].

Функціональні особливості системи дозволяють відстежувати весь процес, починаючи від планування, проведення самої процедури, оголошення закупівлі, подачі та оцінки пропозиції, підписання контракту та врешті решт сплати коштів.

Висновки та перспективи подальших досліджень. Запровадження системи електронних торгів у сфері державних закупівель - це новаційний метод, за допомогою якого бюджетні установи і суб'єкти господарювання мають змогу управляти електронним середовищем на всіх етапах закупівельного циклу. Цей цикл включає як маркетингові дослідження, так i процедури придбання, розміщення замовлень, здійснення поставок i оплат за них, бюджетування й планування закупівель формування бюджету закупівель і його реалізацію.

Державні закупівлі постійно привертають публічну увагу як потенційне джерело корупції, невиправданих розтрат коштів платників податків. Попри те, що система публічних закупівель є унікальною та визнаною міжнародними фахівцями, вона потребує нормативного та постійного технічного вдосконалення. До структури входять кошти державного та місцевих бюджетів, а також кошти державних та комунальних підприємств. Фактично, це кошти, які кожного дня громадяни України сплачують державі у вигляді податків та інших обов'язкових внесків.

Аналіз сучасного стану функціонування системи державних закупівель, антимонопольного регулювання та конкуренції в Україні свідчить, що у цій сфері досягнуто позитивних результатів та зрушень в сторону розвинених країн.

Покращення системи закупівель необхідне для того, щоб забезпечити прозорість процесу державних закупівель, підвищити довіру бізнесу до держави й ефективність у боротьбі з корупцією.

Йдеться передусім про забезпечення раціонального i прозорого використання державних коштів, тобто державні закупівлі повинні здійснюватися на основі ключового принципу: ділова співпраця через конкурентний механізм. Покращення системи відкритих конкурентних держзакупівель має дати потужний поштовх розвитку української економіки.

Налагодження ділової цивілізованої конкуренції, рішуча 
антимонопольна політика прискорять встановлення національного продуктивного ринку. Замість нещадної конкурентної боротьби важливо враховувати кращі зразки світового досвіду, намагатися знаходити способи ділового співробітництва у процесі розподілу сфер підприємницької діяльності, залучення кращих технологій, сприяння взаємовигідному партнерству товаровиробників.

Суспільство та влада повинні контролювати, які саме товари, роботи та послуги закуповуються державними інституціями, органами місцевого самоврядування за рахунок бюджету, чому саме ці товари та послуги вважаються необхідними для суспільних потреб, якою є загальна вартість таких товарів та послуг, їхня якість, яким чином проводяться процедури закупівлі. Саме національні зусилля боротьби 3 корупцією супроводжуються позитивними стимулами. Разом, заходи 3 виховання доброчесності та відповідні нормативні акти являють собою систему стримувань і противаг, яка починає і стримує корупцію.

\section{Jimepamypa:}

1. Порядок функціонування електронної системи закупівель i проведення авторизації електронних майданчиків: постанова Кабінету Міністрів України від 16.03. 2016p. №166 URL: http://www.searsh.ligazakon.ua.

2. Вареник В. Особливості застосування системи державних закупівель prozorro. Європейський вектор економічного розвитку. 2016. №2 (21). C. 6-15.

3. Кулак Н. Сучасний етап і перспективи розвитку електронізації державних закупівель в Україні. Вісник АМСУ. 2014. №2.(11). С. 82-86.

4. Міняйло В. Організація електронних державних закупівель. Вісник КНTEУ. 2012. №3. C. 36-44.

5. Про адміністративні правопорушення: кодексУкраїни від 07.12.1984 № 8073-X ст. 16414 URL: http://zakon.rada.gov.ua/laws/ show/80731-10.

6. Чабан В. Електронні державні закупівлі: на шляху до інтеграції ЄС. Юридична газета. 2015. №52(498). C. 22-23 URL: http://www.vkp.ua/ content/news.

7. Ткаченко Н. Б Дослідження механізму здійснення державних закупівель в Україні. Вісник КНТЕУ. 2005. № 3. С. 32-35.

8. Наказ Державного комітету України 3 питань технічного регулювання та споживчої політики від 28.7.2010 року №327 у редакції 
відповідно до зміни №5, затвердженої наказом Мінекономрозвитку від 10.08.2016 №1328.

\section{References:}

1. Porjadok funkcionuvannja elektronnoji systemy zakupivelj i provedennja avtoryzaciji elektronnykh majdanchykiv: postanova Kabinetu Ministriv Ukrajiny vid 16.03. 2016r. \#166 URL: http://www.searsh.ligazakon.ua.

2. Varenyk V. Osoblyvosti zastosuvannja systemy derzhavnykh zakupivelj prozorro. Jevropejsjkyj vektor ekonomichnogho rozvytku. 2016. \#2 (21). S. 6-15.

3. Kulak N. Suchasnyj etap i perspektyvy rozvytku elektronizaciji derzhavnykh zakupivelj v Ukrajini. Visnyk AMSU. 2014. \#2.(11). S. 82-86.

4. Minjajlo V. Orghanizacija elektronnykh derzhavnykh zakupivelj. Visnyk KNTEU. 2012. \#3. S. 36-44.

5. Pro administratyvni pravoporushennja: kodeksUkrajiny vid 07.12.1984 \# 8073-X st.16414 URL: http://zakon.rada.gov.ua/laws/show/80731-10.

6. Chaban V. Elektronni derzhavni zakupivli: na shljakhu do integhraciji JeS. Jurydychna ghazeta. 2015. \#52(498). S. 22-23 URL: http://www.vkp.ua/content/news.

7. Tkachenko N. B Doslidzhennja mekhanizmu zdijsnennja derzhavnykh zakupivelj v Ukrajini. Visnyk KNTEU. 2005. \# 3. S. 32-35.

8. Nakaz Derzhavnogho komitetu Ukrajiny $\mathrm{z}$ pytanj tekhnichnogho reghuljuvannja ta spozhyvchoji polityky vid 28.7.2010 roku \#327 u redakciji vidpovidno do zminy \#5, zatverdzhenoji nakazom Minekonomrozvytku vid 10.08.2016 \#1328.

The issue of procurement management in public sector institutions, as a direction of anti-corruption activities, is gaining more and more relevance and significance for our state.

One of the methods of state regulation of the economy is the functioning of the public procurement system. Public procurement is given the role of a promising and important macroeconomic regulator, through which it is possible to form a full-fledged competitive environment, the implementation of stabilization policy in the country.

Transparent procurement mechanism - implemented through the Pgo7oggo system - is a database located on the server and which can not be 
connected directly. It is possible to connect to the Pgo7oggo system only through one of the electronic platforms that have access to the system. Due to this organization of the procurement process, the state cannot interfere in the bidding process, eliminate participants, or somehow influence them. The electronic system is available to any user of information, which strengthens control over the use of budget funds.

Public procurement is constantly attracting public attention as a potential source of corruption, unjustified waste of taxpayers' money. Despite the fact that the public procurement system is unique and recognized by international experts, it needs regulatory and continuous technical improvement. The structure includes funds from the state and local budgets, as well as funds from state and municipal enterprises. In fact, these are funds that Ukrainian citizens pay to the state every day in the form of taxes and other mandatory contributions.

The analysis of the current state of functioning of the system of public procurement, antitrust regulation and competition in Ukraine shows that in this area positive results and shifts towards developed countries have been achieved.

Improving the procurement system is necessary to ensure the transparency of the public procurement process, increase business confidence in the state and be effective in combating corruption.

It is primarily about ensuring the rational and transparent use of public funds, ie public procurement should be based on a key principle: business cooperation through a competitive mechanism. Improving the system of open competitive public procurement should give a powerful impetus to the development of the Ukrainian economy.

Establishing civilized business competition and a decisive antitrust policy will accelerate the establishment of a national productive market. Instead of relentless competition, it is important to take into account the best examples of world experience, try to find ways of business cooperation in the process of dividing the spheres of entrepreneurial activity, attracting better technologies, promoting mutually beneficial partnerships.

Society and government should control which goods, works and services are purchased by state institutions, local governments at the expense of the budget, why these goods and services are considered necessary for public needs, what is the total cost of such goods and services, their quality, how procurement procedures are carried out. It is national anti-corruption efforts that are accompanied by positive incentives. Together, integrity education measures and related regulations are a system of checks and balances that initiates and curbs corruption. 